\title{
Bentonite polymer composite for water purification
}

\author{
GULZIYA A SEILKHANOVA ${ }^{1, *}$, AINUR N IMANGALIYEVA ${ }^{1}$, YITZHAK MASTAI $^{2}$ \\ and AKMARAL B RAKHYM ${ }^{1}$ \\ ${ }^{1}$ Faculty of Chemistry and Chemical Technology, Al-Farabi Kazakh National University, Almaty 050040, Kazakhstan \\ ${ }^{2}$ Department of Chemistry and the Institute of Nanotechnology, Bar-Ilan University, 5290002 Ramat-Gan, Israel \\ *Author for correspondence (g_seilkhanova@mail.ru)
}

MS received 4 January 2018; accepted 29 August 2018; published online 6 March 2019

\begin{abstract}
A polyethylene glycol (PEG)-bentonite (BT) composite was prepared by direct polymerization of PEG in suspensions of BT. Based on detailed analyses using field-effect scanning electron microscopy, X-ray diffraction, surface area measurements and chemical methods, the obtained product was mainly composed of Ca-BT with a specific surface area of $4.13 \mathrm{~m}^{2} \mathrm{~g}^{-1}$. The optimal conditions for adsorption of $\mathrm{Pb}^{2+}$ and $\mathrm{Cd}^{2+}$ ions were found to be a PEG content of $0.1 \%$ and a contact time of $60 \mathrm{~min}$. The sorption experiments were performed under various operating variables, including polymer concentration, $\mathrm{pH}$ and temperature. For both $\mathrm{Pb}^{2+}$ and $\mathrm{Cd}^{2+}$, the adsorption equilibrium was described by the Freundlich model, which confirmed the presence of a heterogeneous system with irregular filling of the active centres. The maximum sorption capacities of BT-PEG for removal of $\mathrm{Pb}^{2+}$ and $\mathrm{Cd}^{2+}$ were found to be 22 and $18 \mathrm{mg} \mathrm{g}^{-1}$, respectively. The rate constants calculated for the sorption of $\mathrm{Pb}^{2+}$ and $\mathrm{Cd}^{2+}$ were 6.29 and $6.67 \mathrm{~g} \mathrm{mg}^{-1} \mathrm{~min}^{-1}$, respectively, at $25^{\circ} \mathrm{C}$. This study shows that the obtained sorbents based on BT may be used for treatment of waste water and could help resolve environmental protection issues.
\end{abstract}

Keywords. Bentonite clay; polyethylene glycol; lead; cadmium; sorption; composite materials.

\section{Introduction}

Lead and cadmium are considered as highly toxic substances. The negative effects of both metals on the human body are manifested even at very low concentrations, for example at 0.25 and $0.005 \mathrm{mg} \mathrm{l}^{-1}$ for $\mathrm{Pb}$ and $\mathrm{Cd}$ in the blood, respectively. An excessive and long-term intake of cadmium in the body leads to development of chronic disease in which the urinary and reproductive systems are affected. Lead is known as a toxic substance for almost 5000 years; its inorganic compounds are enzyme inhibitors and disrupt metabolism [1-4]. Anthropogenic release of heavy metals into the environment is much more significant than natural sources. Huge amounts of lead and cadmium wastes are produced in the automobile, metallurgic, printing and chemical industries, in mining and processing factories and in workshops of metal plating. Major sources for such wastes in Kazakhstan include the Ust-Kamenogorsk lead-zinc plant, copper smelters located in central Kazakhstan, the Petropavlovsk heavy engineering plant, the Aktobe plant of chromium compounds and refineries and other plants. For instance, waste water from the steel and mining industries shows that flotation and enrichment of lead and cadmium ores produce concentrations as high as $5-10 \mathrm{mg}^{-1}[5]$. Chronic poisoning from water containing heavy metal ions, such as lead and cadmium, leads to gradually impaired renal function and nervous system, to water deficiency and to anaemia.

Ion exchange and sorption methods are widely used for purification of waste water [6-8]. These methods are based on the use of solid adsorbents and are effective for the purification of water from various metals. Solid adsorbents for purification of waste water are typically produced by simple synthesis at relatively low cost and exhibit high sorption characteristics [9-11]. Many adsorbents, such as clay materials, activated carbon, cellulose and its derivatives and metal oxides, have a high capacity for sewage treatment and have been used as adsorbents for water purification [12-14]. Activated carbon is considered to be a particularly competitive and efficient sorbent for the removal of heavy metal ions [14]. Nevertheless, the use of activated carbon is not suitable in certain cases due to the high costs associated with its production and regeneration. In this work, we used clay sorbents, which play a significant role in purification processes applied to aqueous solutions of inorganic and organic pollutants $[15,16]$. However, in a natural state, many clay sorbents do not have high adsorption capability, so they are usually modified to provide improved adsorptive and catalytic properties. Thermal activation, acid and alkali processing and various complexing 
agents such as polymers and organic substances are widely used methods for activation of natural sorbents [17-19]. Semisynthetic sorbents, which contain donor atoms, are composite materials that are prepared from natural minerals, for example by chemisorption of organic or inorganic compounds or by precipitation on simple or complex oxides. As a result, sorbents are obtained with different kinds of surfaces and pore structures. For instance, semi-synthetic organo-bentonite (BT), a natural montmorillonite clay, was pillared by polyhydroxyl ferric and aluminium, $\mathrm{MnCl}_{2}, \mathrm{TiCl}_{4}$, chitosan and other means; polyacrylamide, polycarboxylic acid, poly(2hydroxyethyl methacrylate) and other polymers can serve as a continuous phase in the composite [20-22].

The aim of this work was to establish the physical and chemical characteristics of modified clay sorbent based on BT and to study the sorption of lead and cadmium ions. In our work, the BT clay was modified with a polymeric ligand, namely polyethylene glycol (PEG), which is a non-toxic and widely available reagent [23]. PEG is polar, miscible in water and compatible with aqueous clay mineral suspensions, and interacts at the molecular level. The hydroxyl groups present on montmorillonite and the water bound to the exchangeable cations readily form hydrogen bonds with the hydroxyl groups of the PEG chains [24].

\section{Experimental}

\subsection{Materials}

The following materials were used in this work: Camontmorillonite (BT) from Dinosaur deposits (95\% purity), purchased from the B-clay company (Kazakhstan); watersoluble PEG, produced by AppliChem GmbH (Germany) with molecular weight of $6000 \mathrm{~g} \mathrm{~mol}^{-1} ; \mathrm{Pb}\left(\mathrm{NO}_{3}\right)_{2}$ and $\mathrm{CdCl}_{2} \cdot 2 \mathrm{H}_{2} \mathrm{O}$. All chemicals were of analytical grade.

\subsection{Preparation of composite BT-PEG}

The modification of BT clay was conducted with several concentrations of PEG by standard procedure [25]. For this purpose, five samples of sorbent were prepared: $20 \mathrm{~g}$ natural BT was dispersed in $100 \mathrm{ml}$ of $0.1,0.5,1.0,2.0$ and 5.0\% aqueous solutions of PEG, respectively, under continuous stirring. This dispersion was stirred at $25^{\circ} \mathrm{C}$ for $1 \mathrm{~h}$ and left for $24 \mathrm{~h}$ at ambient temperature. The prepared BT-PEG was separated by paper filtration, washed several times with deionized water and dried at $100^{\circ} \mathrm{C}$ for $4 \mathrm{~h}$. Obtained sorbents were ground to a powder of $70 \mu \mathrm{m}$ in size using a porcelain mortar.

\subsection{Sorbent characterization}

The morphology and particle dispersion were investigated by field-emission scanning electron microscopy (FE-SEM, FEI QUANTA 3D 200i). The chemical composition of the modified BT was measured by energy-dispersive X-ray spectroscopy (EDX) performed in a SEM. Structural features were investigated by X-ray diffraction (XRD) spectroscopy (AXS D-8 Advance, Bruker) with $\mathrm{CuK} \alpha(\lambda=1.5418 \AA)$ operating at $40 \mathrm{kV} / 40 \mathrm{~mA}$. The textural features were also measured by nitrogen sorption (Quantachrome NOVA 4200e) at $-196^{\circ} \mathrm{C}$. The specific surface area $\left(S_{\mathrm{BET}}\right)$ was calculated according to the Brunauer-Emmett-Teller (BET) theory up to a relative nitrogen pressure of 0.2 . Sorbent moisture was determined by mass difference from the initial sample weight of $1 \mathrm{~g}$ after drying at $110^{\circ} \mathrm{C}$ for $1 \mathrm{~h}$ in a weighing bottle [26]. Ash content was determined by mass difference from the initial sample weight of $1 \mathrm{~g}$ after calcination at $900^{\circ} \mathrm{C}$ for $2 \mathrm{~h}$ [27]. The total gross porosity of water and acetone was determined by absorption for $30 \mathrm{~min}$ at room temperature [28]. Adsorption activity of iodine was determined by titration with sodium thiosulphate according to the ASTM procedure [29].

\subsection{Adsorption experiments}

The sorption process was investigated in static conditions. The adsorption of heavy metals was performed by mixing $1 \mathrm{~g}$ of adsorbent with a $100 \mathrm{ml}$ solution of known solute $\left(\mathrm{Pb}^{2+}\right.$ or $\mathrm{Cd}^{2+}$ at 2-250 $\mathrm{mg} \mathrm{l}^{-1}$ ) at constant temperature until equilibrium was reached. The equilibrium time was determined from curves of changes in adsorption capacity with contact time. Samples were taken every $30 \mathrm{~min}$ from the aqueous solution for determination of metal content; the metal concentration was determined by an atomic absorption spectrometer (Shimadzu 6200). The sorption capacity $q\left(\mathrm{mg} \mathrm{g}^{-1}\right)$ was obtained as follows:

$$
A=\frac{C_{0}-C_{\mathrm{e}}}{m} V
$$

where $C_{0}$ and $C_{\mathrm{e}}$ are the initial and equilibrium concentrations $\left(\mathrm{mg} \mathrm{l}^{-1}\right)$ of metal ions in the aqueous solution, respectively, $V$ is the volume of the metal ion solution (1) and $m$ is the weight of sorbent $(\mathrm{g})$. To study the effect of $\mathrm{pH}$ on the sorption, $1 \mathrm{~g}$ of sorbent was dispersed in $100 \mathrm{ml}$ solutions containing $100 \mathrm{mg} \mathrm{l}^{-1}$ of each heavy metal ion at $25^{\circ} \mathrm{C}$. The initial $\mathrm{pH}$ values were adjusted from 2 to 6 by adding $\mathrm{HCl}$ from a $0.1 \mathrm{~N}$ solution, and $\mathrm{pH}$ measurements were performed using a pX-150MI pH-meter.

\section{Results and discussion}

\subsection{Characterization of the sorbent}

The obtained BT-PEG sorbent was thoroughly characterized by EDX, FE-SEM, XRD and BET analysis. Existence of $\mathrm{Ca}$ (55.54\% w/w), Si, Al, Mg, Na, Fe and $\mathrm{O}$ was observed by elemental analysis (see supplementary table S1 of the Supporting Information). High calcium content in the original and modified BT-PEG sorbent indicates effective sorption capability [30]. After modification, a slight increase in carbon and 
oxygen content and decrease in calcium content can be seen, which confirm the successful synthesis of BT-PEG.

Physico-chemical and textural characterization of the initial and modified BT sorbent is summarized in table 1. BT in its dry state was shown to have a moisture content of around $8.6 \%$ and ash content of $6.4 \%$. Moreover, the data show that modification of the initial BT clay leads to a significant reduction in the total pore volume of acetone (from 29.05

Table 1. Textural characterization of BT and BT-PEG.

\begin{tabular}{lcc}
\hline Characterization & BT & BT-PEG \\
\hline Moisture, \% & 8.6 & 4.9 \\
Ash content, \% & 6.4 & 23.3 \\
The total pore volume of acetone, $\%$ & 29.05 & 19.12 \\
Adsorption activity on iodine, $\%$ & 30.60 & 40.00 \\
The total pore volume of water, $\mathrm{cm}^{3} \mathrm{~g}^{-1}$ & 0.010 & 0.009 \\
\hline
\end{tabular}

to $19.12 \%$ ), which indicates a reduction in the number of mesopores. In addition, the increase in iodine adsorption (from 30.60 to $40.00 \%$ ) indicates an improvement in the microporous structure. Water sorption measurements indicated that the total pore volume decreased as a result of the polymer modification. Hence, we conclude that the modification of BT by PEG leads to a predominance of mesoand micro-pores in the sorbent structure, which significantly enhance the adsorption of heavy metal ions.

Figure 1 shows typical FE-SEM images of non-modified BT and modified BT-PEG after sorption of $\mathrm{Pb}^{2+}$ and $\mathrm{Cd}^{2+}$ ions. Non-modified BT (figure 1A) had significantly uniform texture provided primarily by micropores with a diameter in the range of 1-4 $\mu \mathrm{m}$. Needle-shaped growths of the polymer can be seen in this image (figure 1B), which indicates the impregnation of PEG. The near absence of crystallinity after loading the sample with $\mathrm{Pb}^{2+}$ and $\mathrm{Cd}^{2+}$ ions (figure 1C and D) indicates that there was no crystalline phase transformation after sorption.
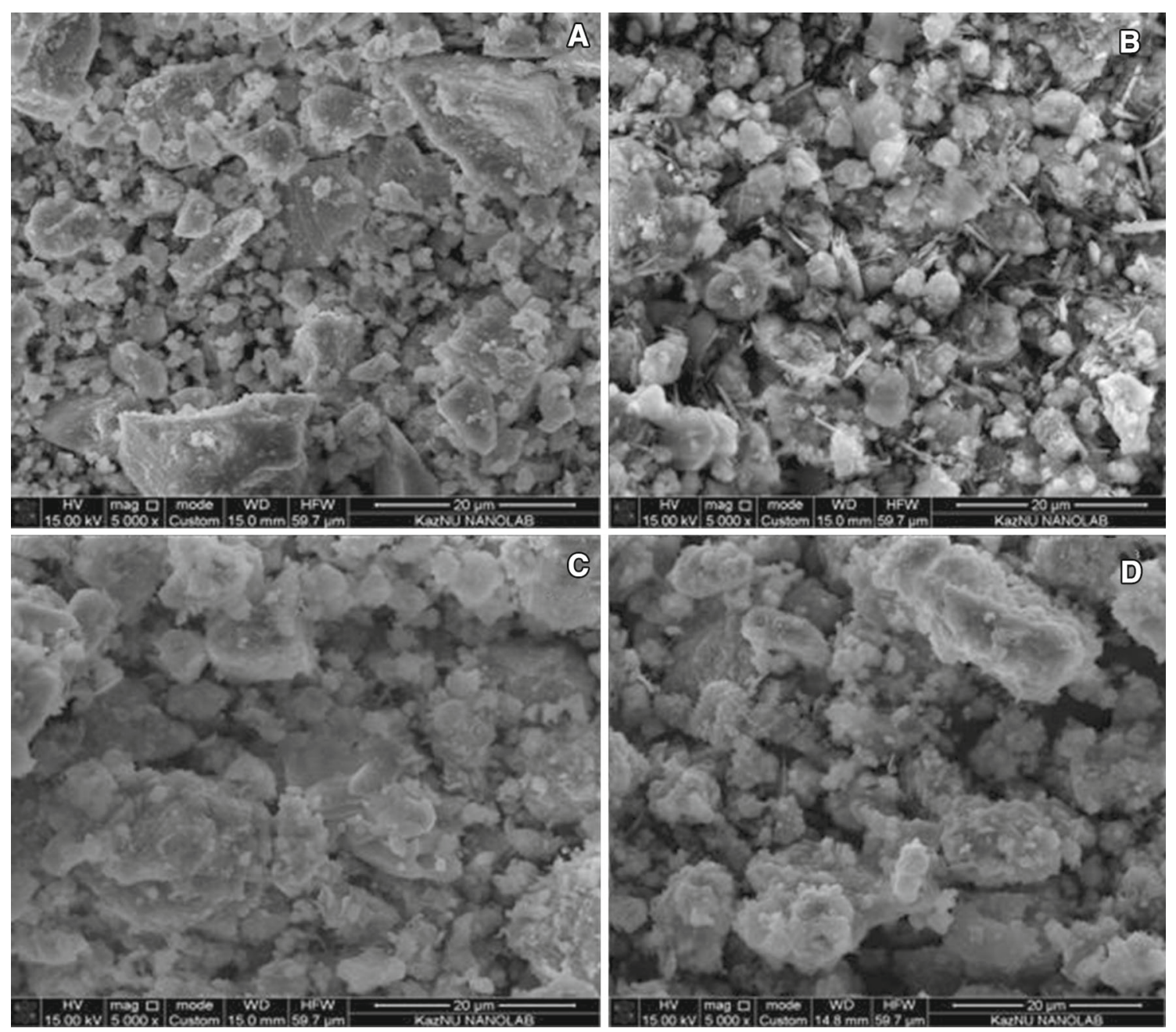

Figure 1. SEM images of sorbents: (A) BT, (B) BT-PEG, (C) BT-PEG-Pb and (D) BT-PEG-Cd. 


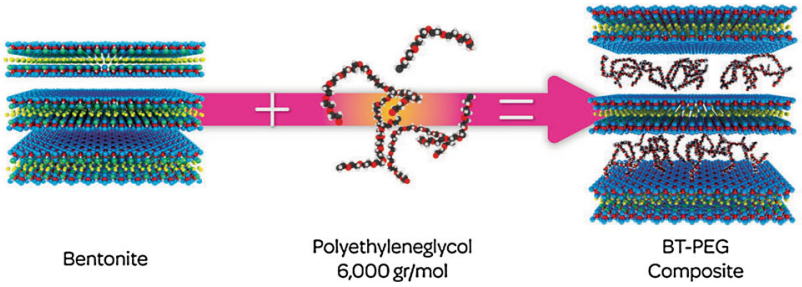

Figure 2. Schematic illustration of BT modification by PEG.

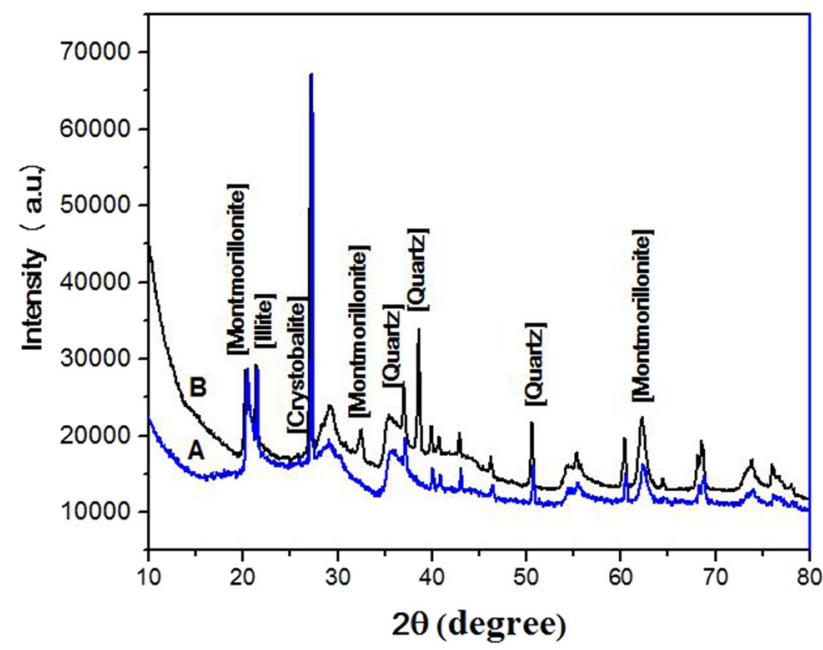

Figure 3. XRD patterns of: (A) natural BT and (B) BT-PEG.

It is known that montmorillonite is the main mineral of BT; it has a 2:1 layer structure, consisting of an octahedral alumina sheet sandwiched between opposing tetrahedral silica sheets [31]. The bonding between the two silica sheets is very weak, allowing water and exchangeable ions to enter. It was assumed that adsorption of PEG can occur on both external surface and interlayer spaces (figure 2). Then, the adsorption proceeds according to the ion-exchange mechanism, which is presented for BT and PEG in equations (2 and 3) as follows:

$$
\begin{aligned}
& 2 \equiv \mathrm{Si}-\mathrm{O}-\mathrm{H}+\mathrm{Me}^{2+} \\
& \quad \rightarrow \equiv \mathrm{Si}-\mathrm{O}-\mathrm{Me}^{2+}-\mathrm{O}-\mathrm{Si} \equiv+2 \mathrm{H}^{+} \\
& 2 \mathrm{OH}-\left(\mathrm{CH}_{2}-\mathrm{CH}_{2}-\mathrm{O}\right)_{n}-\mathrm{H}+\mathrm{Me}^{2+} \\
& \quad \rightarrow \mathrm{OH}-\left(\mathrm{CH}_{2}-\mathrm{CH}_{2}-\mathrm{O}\right)_{n} \\
& \quad-\mathrm{Me}^{2+}-\mathrm{O}-\left(\mathrm{CH}_{2}-\mathrm{CH}_{2}-\mathrm{O}\right)_{n}+2 \mathrm{H}^{+}
\end{aligned}
$$

The XRD patterns of raw BT (A) and modified BT (B) are shown in figure 3. The raw BT contains characteristic diffraction peaks of montmorillonite $(\mathrm{M})$, which are located at $2 \theta=20.49,32.64$ and 62.54 and quartz $(\mathrm{Q})$, where the characteristic peaks are located at $2 \theta=37.14,39.02$ and 50.85, respectively. The other peaks are impurities corresponding to cristobalite, field spar and illite [32]. However, as can be seen in the diffraction pattern of BT-PEG shown in figure 3, while there is a change in the intensity of the peaks, the appearance of new peaks is not detected. This might be due to the low concentration of the modifying agent or the high dispersion of polymer particles in the BT matrix. EDS data showing PEG particles fixed onto the surface of BT are given in supplementary table S1 of the Supporting Information.

Adsorption isotherms enable us to draw conclusions about the surface area, the porosity of the adsorbent and the nature of the interaction between the sorbent and the sorbate. Figure 4 shows $\mathrm{N}_{2}$ adsorption-desorption isotherms indicating that the surface area, total pore volume and average pore diameter decreased significantly by modifying the BT by PEG, from 4.13 to $3.67 \mathrm{~m}^{2} \mathrm{~g}^{-1}, 0.0131$ to $0.0082 \mathrm{~cm}^{3} \mathrm{~g}^{-1}$ and 222 to $186 \mathrm{~nm}$, respectively. This reduction in the values of the characteristic attributes of the BET theory was assumed to arise due to the introduction of the polymer in the pores of the initial BT. However, from figure 4c, we can see that the modified BT has a narrow pore size distribution of about $2-4 \mathrm{~nm}$.

\subsection{Removal of $\mathrm{Pb}^{2+}$ and $\mathrm{Cd}^{2+} \mathrm{BT}-\mathrm{PEG}$}

3.2a Effect of modifier (PEG) concentration and sorbent dose: First, we studied the effect of the polymer concentration in the BT-PEG material on the adsorption of the metal ions. The effect of the PEG concentration was studied at $25^{\circ} \mathrm{C}$, and the results are presented in figure 5. It was found that increasing the concentration of polymer in the BT-PEG material increases the amount of adsorbed metal ions. This behaviour might be due to the fact that at higher polymer concentrations, metal ions are adsorbed onto the sorbent surface not only by the mechanism of physical sorption, but also by functional groups of PEG. The saturation period of the sorbent is defined by the nature of both adsorbent and sorbate. The sorption equilibrium of lead and cadmium ions occurs within $60 \mathrm{~min}$; this short time period required to attain equilibrium suggests an excellent affinity of the metal ions for the BT-PEG composite.

Based on these graphs, regardless of the quantity of the modifying polymer, all sorbents almost completely adsorbed the lead and cadmium ions. Therefore, for economic efficiency, the sorbent containing the minimum quantity of PEG $(0.1 \%)$ was selected for further studies.

Supplementary figure S1 of the Supporting Information reveals the effect of the adsorbent dose on the adsorption characteristics. Comparative analysis shows that the optimal dose of adsorbent for removal of lead and cadmium ions is $10 \mathrm{~g} \mathrm{l}^{-1}$. This dose is quite high, but due to the low-cost and non-toxic properties of BT-PEG, this composite can be applied.

3.2b Effect of $p H$ : It is known that at $\mathrm{pH}$ values above 6, most of the heavy metals tend to form hydroxides, which can mask the 'true' degree of adsorption. Therefore, the dependence of the adsorption on the acidity of the metal ion solutions was studied at $\mathrm{pH}$ values ranging from 2 to 6 . The effect of $\mathrm{pH}$ on adsorption of lead and cadmium ions onto pure BT was investigated earlier [25]. For BT-PEG, the effect of $\mathrm{pH}$ is shown in figure 6. At $\mathrm{pH}$ values ranging from 3 to 5 , 

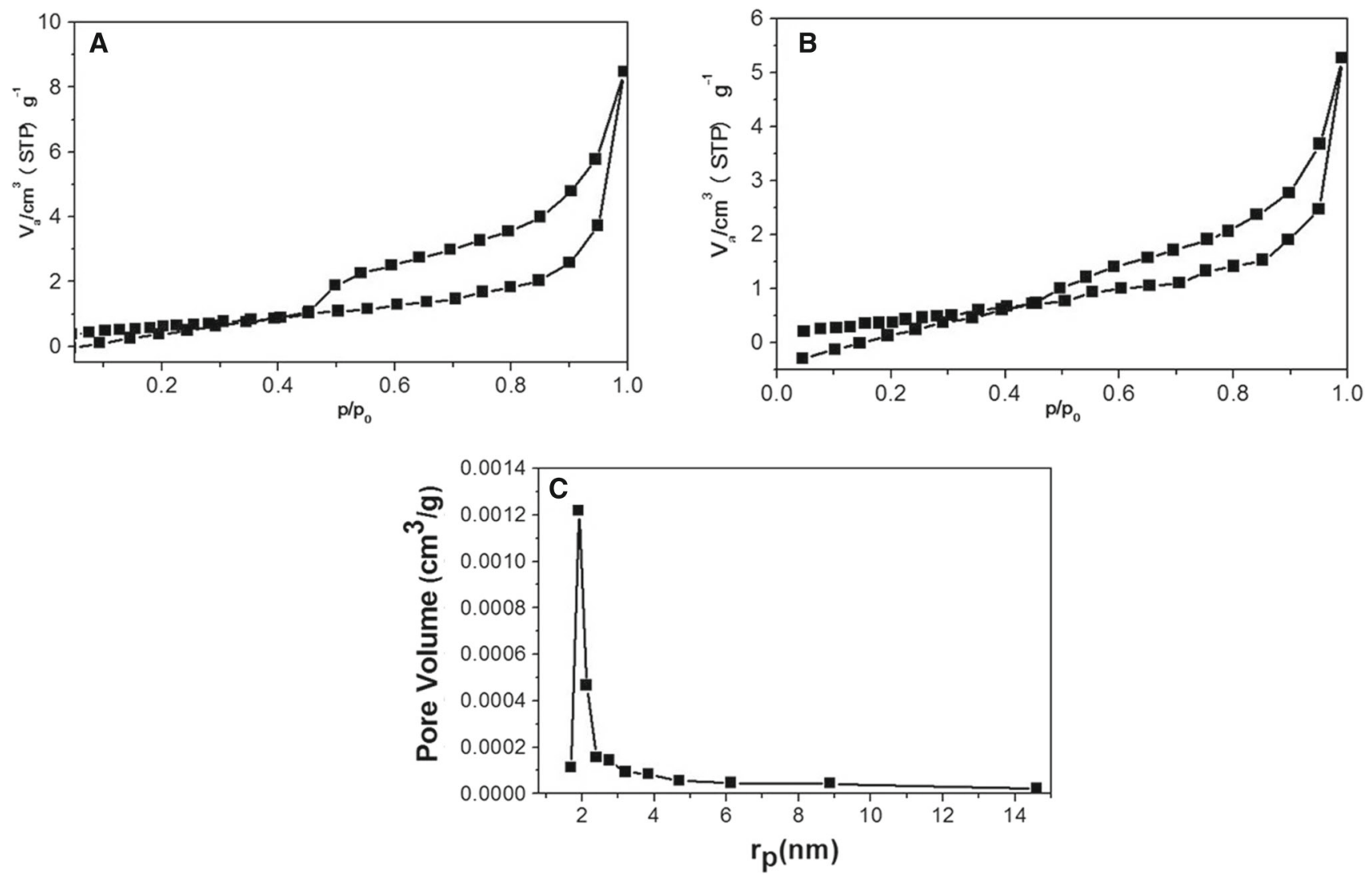

Figure 4. $\mathrm{N}_{2}$ adsorption-desorption isotherms of: (A) BT, (B) BT-PEG and (C) Barrett-Joyner-Halenda (BJH) pore size distribution plot of the BT-PEG.
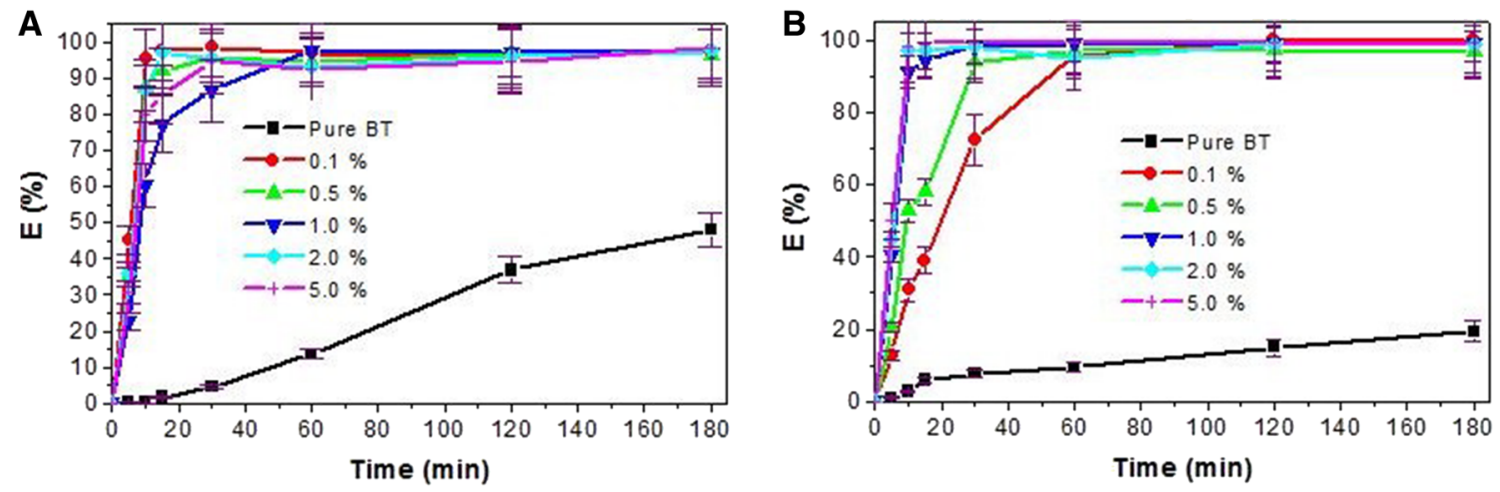

Figure 5. Effect of PEG concentration on the extent of adsorption of: (A) $\mathrm{Pb}^{2+}$ and $(\mathbf{B}) \mathrm{Cd}^{2+}$ ions onto BT-PEG (adsorbent dose $=10 \mathrm{~g}^{-1} ; \mathrm{pH}=6$; temperature $=25^{\circ} \mathrm{C}$ ).

the adsorption capacity of $\mathrm{Cd}^{2+}$ is higher than $\mathrm{Pb}^{2+}$, while at $\mathrm{pH}$ 6, both ions showed similar adsorption capacity.

At low $\mathrm{pH}$ values, which correspond to a high proton concentration, there is competition between the $\mathrm{H}^{+}$and the $\mathrm{Pb}^{2+}$ and $\mathrm{Cd}^{2+}$ ions for the negatively charged surface of the sorbent [33].

\subsection{Adsorption isotherms}

The effect of the initial concentration of metal ions on their adsorption was studied at $25^{\circ} \mathrm{C}$ in a broad range of 2 $250 \mathrm{mg} \mathrm{l}^{-1}$. According to the obtained isotherms (figure 7), the modified sorbent showed maximum adsorption of 22 and 


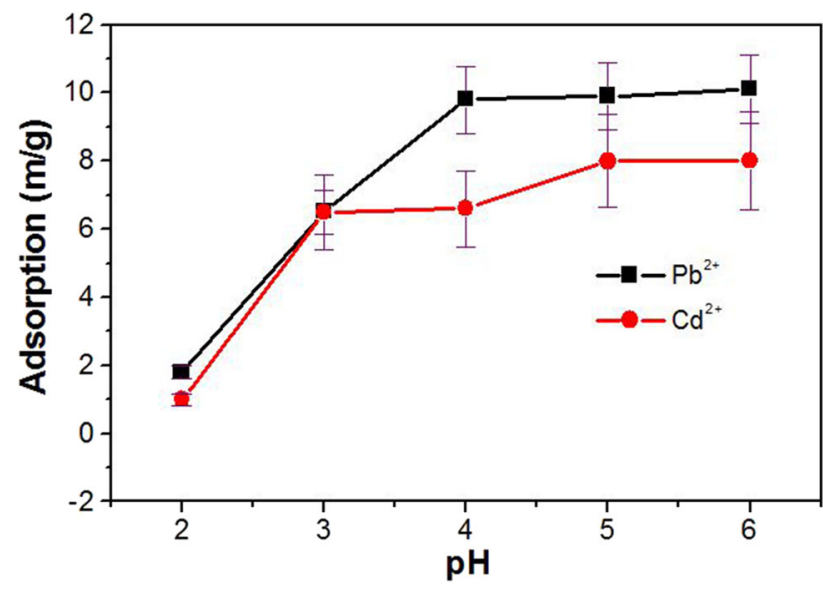

Figure 6. Effect of $\mathrm{pH}$ on heavy metal adsorption by BT-PEG (initial metal ion concentration $=100 \mathrm{mg}^{-1}$; adsorbent dose $=10 \mathrm{~g} \mathrm{l}^{-1}$; temperature $=25^{\circ} \mathrm{C}$ ).

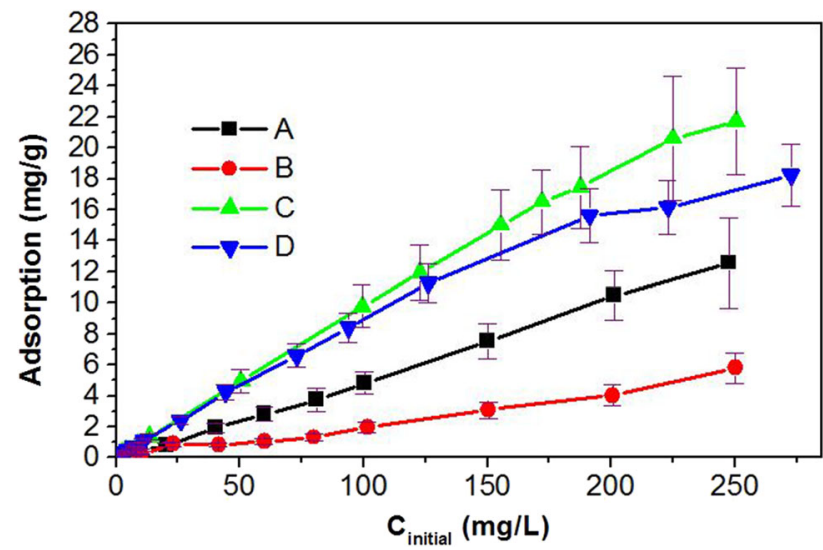

Figure 7. Adsorption isotherms on $(\mathbf{A}) \mathrm{Pb}^{2+},(\mathbf{B}) \mathrm{Cd}^{2+}$ ions onto $\mathrm{BT}$ and $(\mathbf{C}) \mathrm{Pb}^{2+}$ and $(\mathbf{D}) \mathrm{Cd}^{2+}$ onto BT-PEG (contact time $=$ $180 \mathrm{~min}$; adsorbent dose $=10 \mathrm{~g} \mathrm{l}^{-1} ; \mathrm{pH}=6$; temperature $=25^{\circ} \mathrm{C}$ ).

$18 \mathrm{mg} \mathrm{g}^{-1}$ for lead and cadmium ions, respectively, whereas pure BT showed considerably lower maximum adsorptions of 13 and $6 \mathrm{mg} \mathrm{g}^{-1}$ for lead and cadmium, respectively. Sorption isotherms are important for describing the adsorption process, as they show how the metal ions are distributed between the adsorbent and liquid phase at equilibrium depending on the concentration. In this work, to describe the sorption of heavy metal ions by the investigated sorbent, the two of the most commonly used models were applied: the Langmuir and Freundlich isotherms. The following isotherm constants were calculated: $K$ the equilibrium constant of the adsorption process, $A_{\infty}$ the limiting adsorption, $\beta$ the the Freundlich parameter and $1 / n$ the heterogeneity factor. It can be seen from table 2, the Langmuir isotherm does not conform to either of the two metal sorption processes, as evidenced by the values of the $R^{2}$ correlation coefficient, which were 0.886 and 0.703 for $\mathrm{Pb}^{2+}$ and $\mathrm{Cd}^{2+}$ ions, respectively.
Table 2. Characterization of adsorption isotherms of metal ions at $25^{\circ} \mathrm{C}$.

\begin{tabular}{|c|c|c|c|c|c|c|}
\hline \multirow{2}{*}{ Metal } & \multicolumn{3}{|c|}{ Langmuir model } & \multicolumn{3}{|c|}{ Freundlich model } \\
\hline & $K, \mathrm{mg}^{-1}$ & $A_{\infty}, \mathrm{mg} \mathrm{g}^{-1}$ & $R^{2}$ & $\rho$ & $1 / n$ & $R^{2}$ \\
\hline
\end{tabular}

BT

$\begin{array}{lllllll}\mathrm{Pb}^{2+} & 0.05 & 1.35 & 0.397 & 14.45 & 1.187 & 0.979 \\ \mathrm{Cd}^{2+} & 0.18 & 0.26 & 0.541 & 15.35 & 0.393 & 0.604\end{array}$

BT-PEG

\begin{tabular}{lllllll}
$\mathrm{Pb}^{2+}$ & 1.35 & 4.46 & 0.886 & 3.82 & 0.91 & 0.919 \\
$\mathrm{Cd}^{2+}$ & 2.45 & 3.34 & 0.703 & 2.30 & 0.53 & 0.915 \\
\hline
\end{tabular}

The data from adsorption studies are best described by the Freundlich isotherm (figure $8, R^{2}=0.919$ for lead and $R^{2}=0.915$ for cadmium). Therefore, the sorption of metal ions by BT-PEG proceeds in good agreement with the Freundlich isotherm model in which the extraction of metal ions occurs in a heterogeneous system with uneven filling of the active centres and the visible forces of interaction between the adsorbed particles.

\subsection{Adsorption kinetics}

In the present study, pseudo-first-order and pseudo-secondorder kinetic models were employed to test the experimental data [34]. The pseudo-first-order and pseudo-second-order models are described by the following equations, respectively:

$$
\begin{aligned}
& \ln \left(q_{\mathrm{e}}-q_{\mathrm{t}}\right)=\ln q_{\mathrm{e}}-k_{1} t \\
& \frac{t}{q_{\mathrm{t}}}=\frac{1}{k_{2} q_{\mathrm{e}}^{2}}+\frac{t}{q_{\mathrm{e}}}
\end{aligned}
$$

where $q_{\mathrm{e}}$ and $q_{\mathrm{t}}$ are the amounts of adsorbate $\left(\mathrm{mg} \mathrm{g}^{-1}\right)$ on the adsorbent at the beginning and at time $t$, and $k_{1}\left(\mathrm{~min}^{-1}\right)$ and $k_{2}\left(\mathrm{~g} \mathrm{mg}^{-1} \mathrm{~min}^{-1}\right)$ are the rate constants of the pseudo-firstorder and pseudo-second-order models, respectively.

The kinetic data were linearized using the pseudo-firstorder and pseudo-second-order models and plotted as $\ln \left(q_{\mathrm{e}}-q_{\mathrm{t}}\right) v s . t$ and $t / q_{\mathrm{t}} v s . t$, respectively.

The constants were calculated from the slope and intercept of the plots and are given in table 3 and shown in figure 9. The results in table 3 indicate that while the pseudo-first-order model applies for pristine BT, better correlation coefficients were obtained for the composite BT-PEG using the pseudo-second-order model, which thus explains the adsorption process better.

To determine the influence of the temperature, the sorption was carried out at 25 and $35^{\circ} \mathrm{C}$. Furthermore, the kinetics was characterized and the activation energy was calculated using 

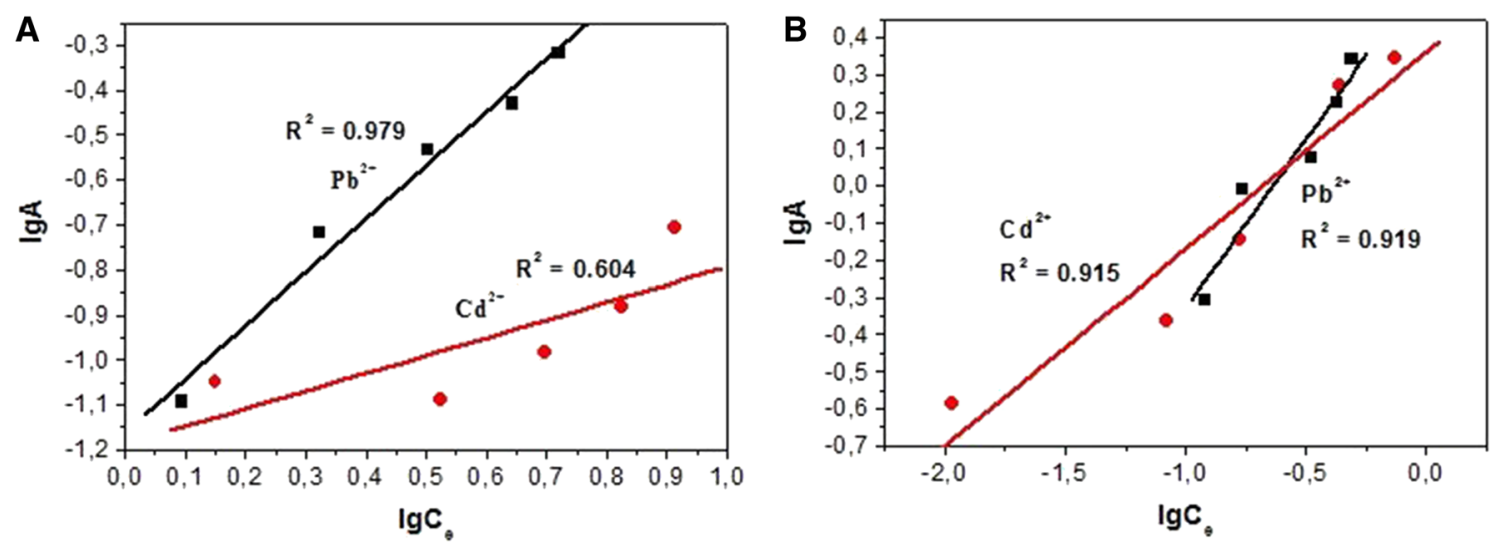

Figure 8. Freundlich isotherm model of heavy metal ion adsorption onto (A) BT and (B) BT-PEG.

Table 3. Kinetic characterization of $\mathrm{Pb}^{2+}$ and $\mathrm{Cd}^{2+}$ sorption onto BT-PEG.

\begin{tabular}{|c|c|c|c|c|c|c|c|c|}
\hline \multirow[b]{2}{*}{ Metal } & \multirow[b]{2}{*}{$C_{0}, \mathrm{mg}^{-1}$} & \multirow[b]{2}{*}{$A_{\max }, \mathrm{mg} \mathrm{l}^{-1}$} & \multirow[b]{2}{*}{$T, \mathrm{~K}$} & \multicolumn{2}{|c|}{ Pseudo-first order model } & \multicolumn{2}{|c|}{ Pseudo-second order model } & \multirow[b]{2}{*}{$E_{\mathrm{a}}, \mathrm{kJ} \mathrm{mol}^{-1}$} \\
\hline & & & & $k_{1}, \min ^{-1}$ & $R^{2}$ & $k_{2}, \mathrm{~g} \mathrm{mg}^{-1} \min ^{-1}$ & $R^{2}$ & \\
\hline \multicolumn{9}{|l|}{ BT } \\
\hline $\mathrm{Pb}^{2+}$ & 5 & 0.16 & 298 & 0.015 & 0.937 & 0.027 & 0.919 & - \\
\hline $\mathrm{Cd}^{2+}$ & 5 & 0.10 & 298 & 0.021 & 0.976 & 0.166 & 0.866 & - \\
\hline \multicolumn{9}{|c|}{ BT-PEG } \\
\hline \multirow[t]{2}{*}{$\mathrm{Pb}^{2+}$} & 5 & 0.52 & 298 & 0.065 & 0.853 & 6.29 & 1 & -10.38 \\
\hline & 5 & 0.49 & 308 & 0.089 & 0.933 & 5.49 & 1 & \\
\hline \multirow[t]{2}{*}{$\mathrm{Cd}^{2+}$} & 5 & 0.46 & 298 & 0.036 & 0.753 & 6.67 & 1 & -34.21 \\
\hline & 5 & 0.32 & 308 & 0.004 & 0.481 & 4.26 & 0.999 & \\
\hline
\end{tabular}
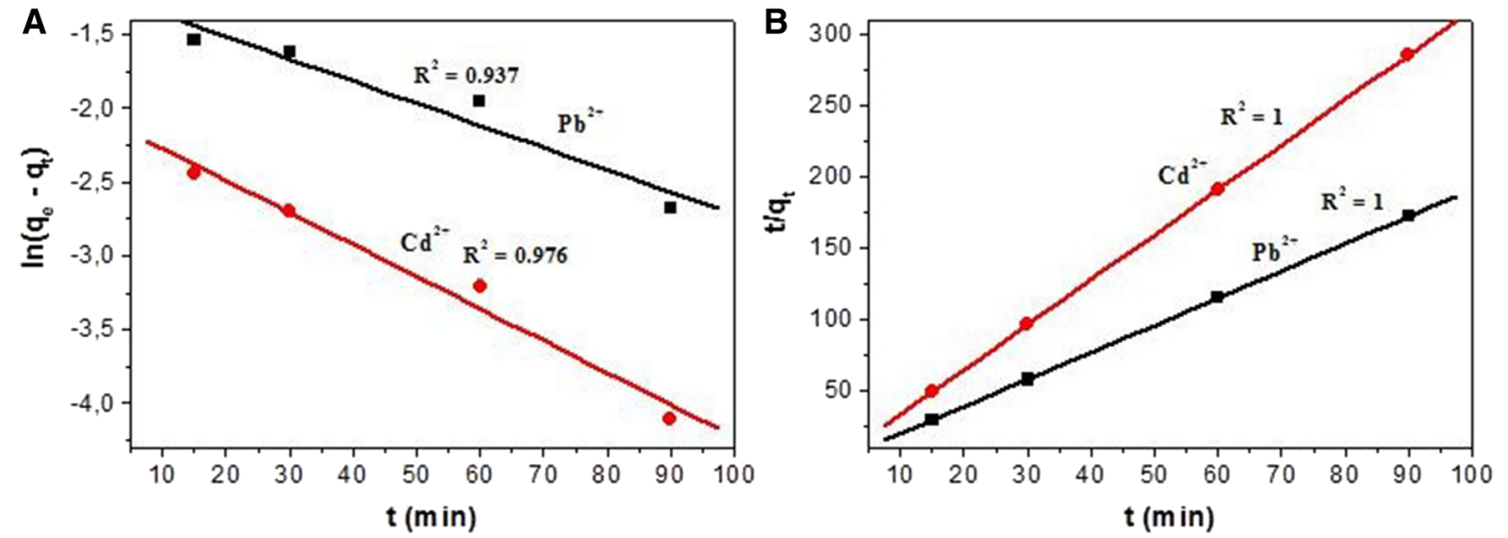

Figure 9. Plots of kinetics of heavy metal ions by (A) pure BT and (B) BT-PEG (initial metal ions concentration $=5$ $\mathrm{mg}^{-1} ;$ adsorbent dose $=10 \mathrm{~g} \mathrm{l}^{-1} ; \mathrm{pH}$ value $=6$; temperature $\left.=25^{\circ} \mathrm{C}\right)$.

the following Arrhenius equation:

$$
E_{\mathrm{a}}=\frac{R T_{1} T_{2} \ln \left(k_{T_{2}} / k_{T_{1}}\right)}{T_{2}-T_{1}}
$$

where $R$ is the gas constant $\left(\mathrm{J} \mathrm{mol}^{-1} \mathrm{~K}^{-1}\right), T_{1}$ and $T_{2}$ are the temperatures $(\mathrm{K})$ at which the sorption was carried out and $k_{T_{1}}$ and $k_{T_{2}}$ are the rate constants at temperatures $T_{1}$ and $T_{2}$. 
The obtained results are presented in table 3 , showing that the rise in temperature has a negative impact on the rate of sorption of both ions. The physical sorption mechanism is supported by the negative value of the activation energy. In addition, the rapid achievement of the equilibrium state (equilibrium time $=60 \mathrm{~min}$ ) also supports a physical adsorption mechanism.

\section{Conclusions}

In summary, BT-PEG sorbent was prepared successfully from BT of the Dinosaur field and used as an adsorbent for removing $\mathrm{Pb}^{2+}$ and $\mathrm{Cd}^{2+}$ from aqueous solutions. SEM, XRD and BET analysis indicate intercalation of the PEG polymer into the initial structure of the BT. The surface area, total pore volume and average pore diameter of BT-PEG were calculated to be $3.67 \mathrm{~m}^{2} \mathrm{~g}^{-1}, 0.0082 \mathrm{~cm}^{3} \mathrm{~g}^{-1}$ and $186.3 \mathrm{~nm}$, considerably lower than the corresponding values for BT. The adsorption of $\mathrm{Pb}^{2+}$ and $\mathrm{Cd}^{2+}$ was found to be dependent on the metal ion concentration, $\mathrm{pH}$ and temperature. The adsorbed amounts of both metal ions increased with increasing PEG concentration, $\mathrm{pH}$. The adsorption equilibrium for both $\mathrm{Pb}^{2+}$ and $\mathrm{Cd}^{2+}$ can be described by the Freundlich model, which confirmed the presence of a heterogeneous system with irregular filling of the active centres. The maximum sorption capacities for $\mathrm{Pb}^{2+}$ and $\mathrm{Cd}^{2+}$ shown by BT-PEG were 22 and $18 \mathrm{mg} \mathrm{g}^{-1}$, respectively. The rate constants for $\mathrm{Pb}^{2+}$ and $\mathrm{Cd}^{2+}$ sorption were found to be 6.29 and $6.67 \mathrm{~g} \mathrm{mg}^{-1} \mathrm{~min}^{-1}$, respectively, at $25^{\circ} \mathrm{C}$.

The results clearly show that the BT-PEG composite is a highly effective sorbent for the extraction of lead and cadmium ions. This facile method of BT clay modification provides a low-cost sorbent, which can be used for purification of waste water at the industrial level.

\section{Acknowledgements}

This work was supported by a grant from the Ministry of Education and Science of the Republic of Kazakhstan 3444/GF4 'Scientific bases development of phosphorus-containing compounds obtained on the basis of technogenic mineral raw materials'.

\section{References}

[1] Elouear Z, Bouzid J, Boujelben N, Feki M, Jamoussi F and Montiel A 2008 J. Hazard. Mater. 156412

[2] Ibrahim H S, Jamil T S and Hegazy EZ 2010 J. Hazard. Mater. 182842

[3] Prasad M, Xu H Y and Saxena S 2008 J. Hazard. Mater. 154 221
[4] Kim K-H, Keller A A and Yang J-K 2013 Colloids Surf. A: Physicochem. Eng. Asp. 4256

[5] Jørgensen S E 1979 Stud. Environ. Sci. 5217

[6] Qu Q, Gu Q, Gu Z, Shen Y, Wang C and Hu X 2012 Colloids Surf. A: Physicochem. Eng. Asp. 41541

[7] Pagnanelli F, Mainelli S, De Angelis S and Toro L 2005 Water Res. 391639

[8] Miretzky P, Saralegui A and Fernández Cirelli A 2006 Chemosphere 62247

[9] Petrus R and Warchoł J K 2005 Water Res. 39819

[10] Sprynskyy M, Buszewski B, Terzyk A P and Namieśnik J 2006 J. Colloid Interface Sci. 30421

[11] Kobya M, Demirbas E, Senturk E and Ince M 2005 Bioresour. Technol. 961518

[12] Rauf N, Ikram M and Tahir S S 1999 Adsorpt. Sci. Technol. 17 431

[13] Al-Asheh S, Banat F and Al-Rousan D 2003 J. Cleaner Prod. 11321

[14] Youssef A M, El-Nabarawy T and Samra S E 2004 Colloids Surf. A: Physicochem. Eng. Asp. 235153

[15] Ma J, Cui B, Dai J and Li D 2011 J. Hazard. Mater. 186 1758

[16] Inglezakis V J, Stylianou M A, Gkantzou D and Loizidou M D 2007 Desalination 210248

[17] Glazacheva E N, Uspenskaya M V and Strelnikova I E 2015 Water Resour. Manag. 196529

[18] Natkański P, Białas A and Kuśtrowski P 2012 Chemik 7 746

[19] Ulusoy U and Şimşek S 2005 J. Hazard. Mater. 127163

[20] Zaharia A, Sarbu A, Radu A L, Jankova K, Daugaard A and Hvilsted S 2015 Appl. Clay Sci. 10346

[21] Sillanpaa A J, Aksela R and Laasonen K 2003 Phys. Chem. Chem. Phys. 53382

[22] Vreysen S and Maes A 2006 Appl. Clay Sci. 32190

[23] Tang W P, Ogo Y, Minamimoto N and Takeoka M 2006 Chem. Lett. 35674

[24] Clegg F, Breen C and Khairuddin M 2014 J. Phys. Chem. B 118 13268

[25] Gupta S S and Bhattacharyya K G 2009 Indian J. Chem. Technol. 16457

[26] Pavlik Z 2006 J. Build. Phys. 3059

[27] Yeboah N N, Shearer C R, Burns S E and Kurtis K E 2014 Fuel 116438

[28] Hook J 2003 Petrophysics 44205

[29] ASTM 2006 Standard test method for determination of iodine number of activated carbon 1 (ASTM Int.)

[30] Tugrul N, Derun E M and Pişkin M 2006 Waste Manage. Res. 24446

[31] Brigatti M F, Galan E and Theng B K G 2006 Dev. Clay Sci. 1 19

[32] Caglar B, Afsin B, Tabak A and Eren E 2009 Chem. Eng. J. 149242

[33] Pyrzyńska K and Bystrzejewski M 2010 Colloids Surf. A: Physicochem. Eng. Asp. 362102

[34] Bogya E S, Baldea I, Barabas R, Csavdari A, Turdean G and Dejeu V R 2010 Stud. Univ. Babes-Bolyai Chem. 2363 